\title{
リパーゼ活性におよばす胆汁酸製㨈の影響
}

\author{
高田充隆, 村上博美, 赤野威彦, 野口利明, ${ }^{* 1}$ 小早川清, 河原 勉*2 \\ 国立大阪病院薬㘊部*1 \\ 国立大阪病院外科*2
}

\section{Effects of Bile Acid Preparations on Lipase Activity}

\author{
Mitutaka TAKadA, Hiromi MURAKami, TAKehiKo AKano, \\ TOSHIAKI NogUchi, ${ }^{* 1}$ KIYOSHI KOBAYAKAWA, TUTOMU KaWAHARA*2 \\ Department of Pharmacy, National Osaka Hospital*1 \\ Department of Surgery, National Osaka Hospital*2
}

(Received July 5, 1985)

\begin{abstract}
The effects of chenodeoxycholic acid (CDCA) and ursodeoxycholic acid (UDCA) on enzymic activity of lipase, as well as the relationship between the lipase activity and the concentration of bile acids in bile, were studied. In the presence of bile administered CDCA, the lipase activity was enhanced significantly. A correlation between the lipase activity and the common logarithm of the concentration of total bile acid and CDCA in bile was observed, correlation coefficients being $0.723(n=30)$ and $0.732(n=30)$, respectively. In addition, it was observed from the result of multiple regression that $\mathrm{CDCA}$ and UDCA increased the lipase activity.
\end{abstract}

Keywords_ - bile; bile acid; lipase activity; chenodeoxycholic acid; urosodeoxycholic acid

緒

近年, 胆汁酸製剤はコレステロール胆石の成因が明ら かになるにつれ，胆石溶解療法として使用される機会が 增加しており，臨床においてはウルソデオキシュール酸 (以下UDCAと略), ケノデオキシュール酸（以下CDCA と略）の製剤が繁用されている。一方胆汁酸が膵りパー ゼの活性を促進し，脂肪の消化吸収に重要な役割を果た していることは広く知られており，これらに関する報告 も多くなされている.1 ${ }^{1 \sim 4}$

今回著者らは，総胆管コレステロール采胆石摘出手術 を受け，UDCA 製剤， CDCA 製剂の投与を受けている 患者から採取した胆汁について，リパーゼ活性促進作用 の比較検討を行うととすに，胆汁中の胆汁酸構成成分と リパーセ活性との関係についても検討を加えた.

$*_{1}, 2$ 大阪市東区法円坂町 2-1；2-1, Hoenzaka-machi, Higashi-ku, Osaka, 540 Japan
実 験 の 部

\section{1. 対 象}

当院外科で総胆管コレステロール系胆石摘出手術を受 けた患者で，手術後 CDCA 製剤 ( $400 \mathrm{mg} /$ day) または UDCA 製剤 $(600 \mathrm{mg} / \mathrm{day})$ の投与を受けている患者お よびこれらの製剤の投与を受けていない患者（CDCA 投 与群 6 名, UDCA 投与群 4 名, コントロール 群 5 名) を対象とした．なお胆汁は手術直後 (以下前胆汁とす る）扣よび手術後約 3 週間の胆汁（以下後胆汁とする） を胆管ドレーンより採取し凍結保存した。

\section{2.リパーゼ活性の測定}

$100 \mathrm{ml}$ の共栓三角フラスコに, 0.2M Tris- $\mathrm{HCl}$ buffer （pH 8.0） $5 \mathrm{ml}$, 胆汁 $1 \mathrm{ml}$, 日局ダイズ油（丸石製薬） $2 \mathrm{ml}$ を加え, 予め $37^{\circ} \mathrm{C}$ に加温後リパーゼ液(420units/ $\mathrm{ml}$, シグマ社製粗リパーゼ) $5 \mathrm{ml}$ を加え， $37^{\circ} \pm 0.5^{\circ} \mathrm{C}$ で 1 時間振とう（100 rpm）し，反応後エタノール，エ ーテル混液 (2: 1) $30 \mathrm{ml}$ を加克反応を止め, $1 \%$ ェ ノールフタレインを指示薬として $0.1 \mathrm{~N}$ 水酸化ナトリウ 
ム液で遊離の脂肪酸を榈定した。この際終点は胆汁の佸 在のため褐色が赤褐色に変化した点とした. 空試験とし てリパーゼ液を加えると同時に反応を止め適定を行いこ の值を差し引いた. な找測定は 4 回（一部 3 回）行いそ の平均をリパーゼ活性值とした。また胆汁のかわりにグ リコケノデオキシュール酸ナトリウム（シグマ社製，以 下 GCDCNa と略) の溶液 $(2,5,10,25,50,75,100$ $\mu \mathrm{mole} / \mathrm{ml}$ ) を用い, 同様の操作を行った.

\section{3. 䏣汁中䏣汁酸灌度の測定}

試料をアルカリ加水分解後エーテル抽出し, ${ }^{5}$ 高速液 体クロマトグラフィーで分離後，3a-ヒドロキシステロ イドデヒドロゲナーゼカラム中で $\mathrm{NAD}^{+}$と反応させ, 生成した $\mathrm{NADH}$ を螢光検出する方法で行った。

\section{結果および考萗}

\section{1. 䏣汁酸製敖投与による䏣汁中䏣汁酸灌度の变化}

各胆汁酸濃度の比較を図 1 亿示した。総胆汁酸（以下 TBA と略) 濃度は, コントロール群, CDCA 投与群, UDCA 投与群とも前胆汁に比べ後胆汁のほうが上昇す る傾向がみられたが, 統計的処理により CDCA 投与群, UDCA 投与群に有意の差が認められた $(\mathbf{p}<0.01)$. ま た各胆汁酸成分についてみると，CDCA 投与群に打いて は CDCA $(\mathrm{p}<0.05)$ V, UDCA 投与群においては, UDCA $(p<0.01)$, コール酸（以下 CA と略）( $p<0.05)$, CDCA $(p<0.05)$ に有意の差が認められた。一般に胆 汁酸製剂を投与した場合，胆汁中の胆汁酸成分は大部分 が投与した成分で占められるとされているが，今回の場
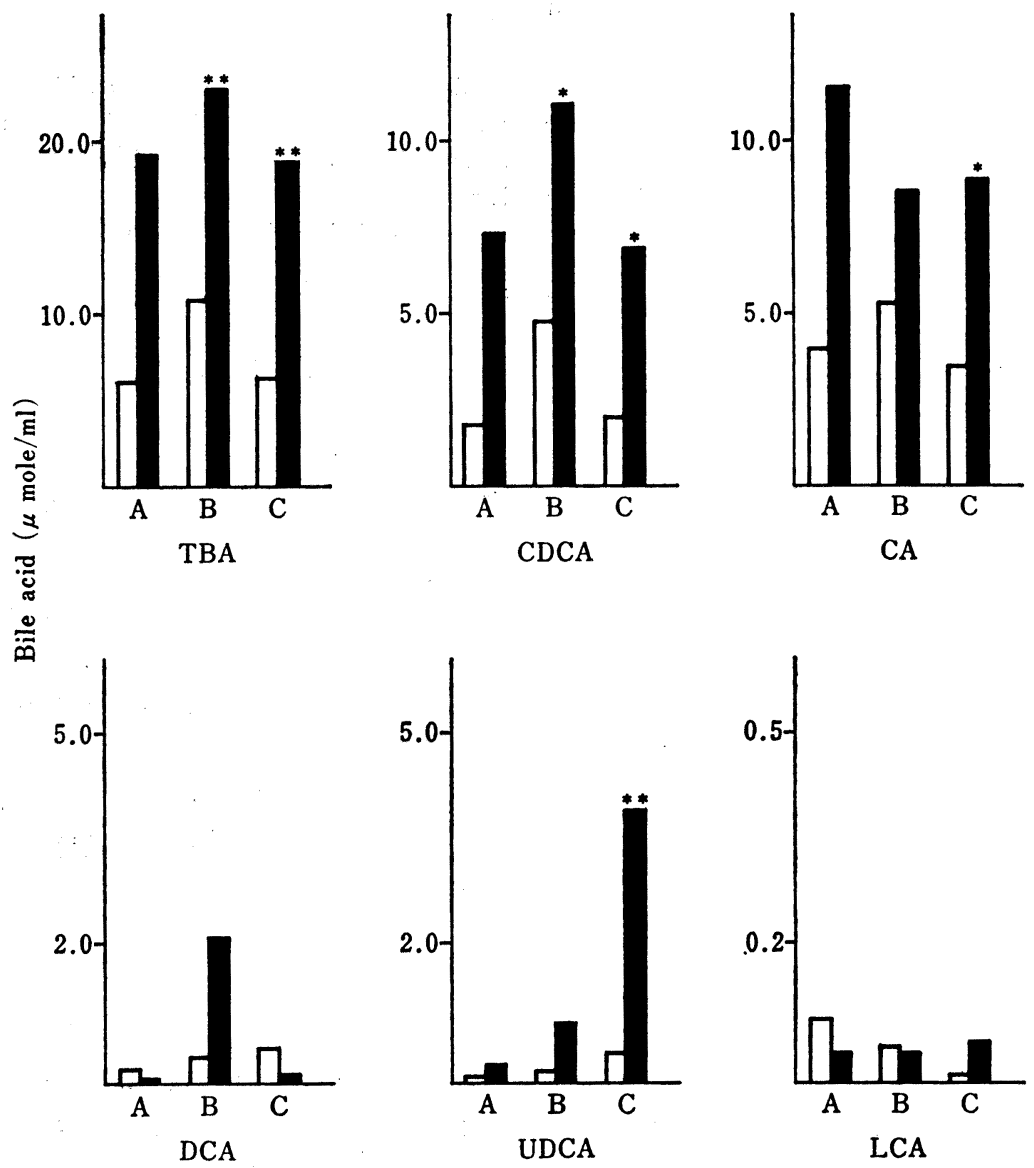

図 1. 各䏣汁酸濩度の比較

$\mathrm{A}:$ : コントロール群, B : CDCA 投与群 (400mg/day), $\mathrm{C}$ : UDCA 投与群 $(600 \mathrm{mg} / \mathrm{day})$

$\square$ 前䏣汁， 後䏣汁 $* \mathrm{p}<0.05, * * \mathrm{p}<0.01$ 


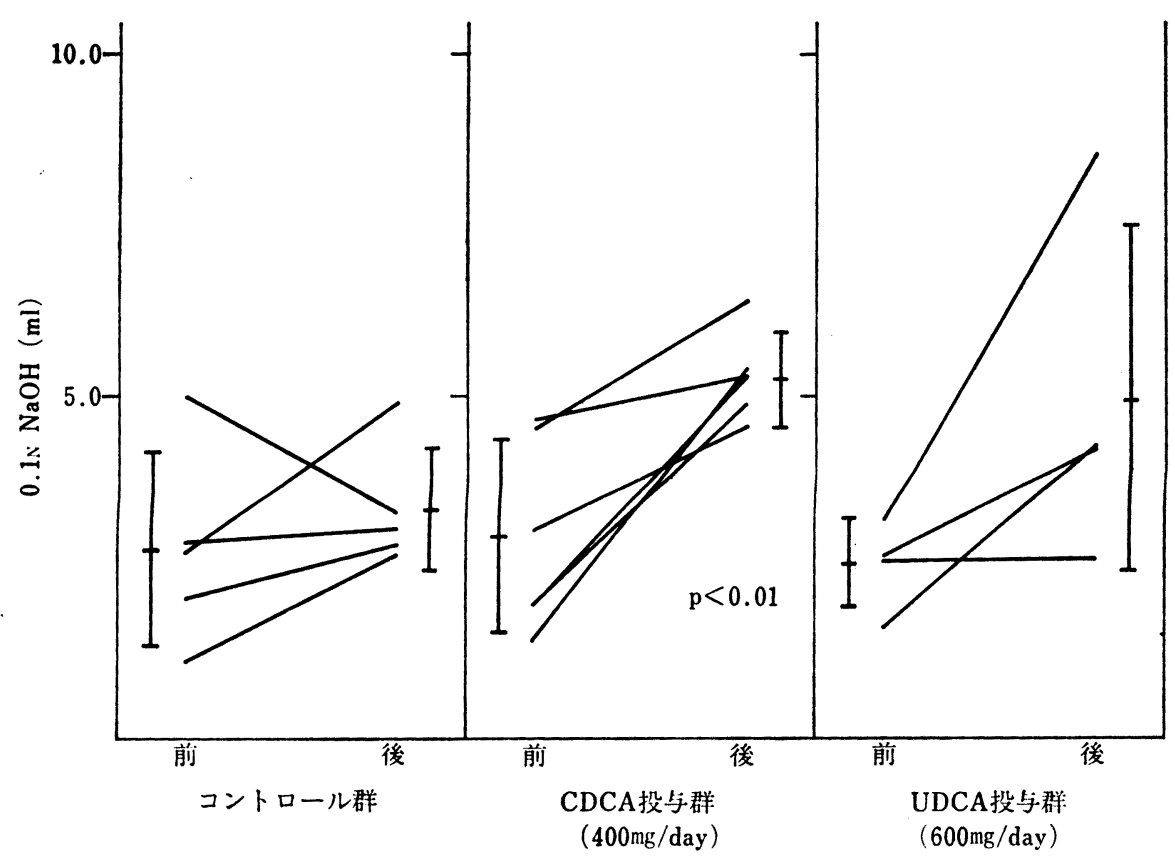

为2. 䏣汁を添加して測定したリパーゼ活性

合，対象が胆管ドレナージにより腸肝循環が一部遮断さ れているため，成分梅成の変化が少なかったものと考え られる。

しかし，CDCA 投与後の胆汁に扣いては，CDCA が 約 $50 \%$ を占め, UDCA 投与後の胆汁では UDCA が約 $20 \%$ ま上䄯していた．また後胆汁における胆汁酸濃度 の上昇には, 腸肝循環遮断による胆汁酸合成のネガティ ブフィードハック機構の関与も考えられる.

2. 䏣汁酸竖剂投与によるリパーゼ活性への影新およ び䏣汁中䏣汁酸湌度とリパーゼ活性との関係

前胆计および後胆汁を添加して測定したリパーゼ活性 を図 2 に示した.リパーセ活性の平均値は、コントロー ル群で $2.75 \mathrm{ml}$ から $3.35 \mathrm{ml}, \mathrm{CDCA}$ 投与群で $2.95 \mathrm{ml}$ から $5.27 \mathrm{ml}$, UDCA 投与群で $2.56 \mathrm{ml}$ から $4.95 \mathrm{ml}$ へ と上昇しているが，統計的処理により CDCA 投与群に 有意差が認められた $(\mathrm{p}<0.01)$. なお三群の前胆汁の間 には有意差を認めなかった.ささらに後胆汁同士の比較に おいて, CDCA 投与群とコントロール群の間に有意差 が認められた（p<0.01）。さたリハーゼ活性は総胆汁酸 濃度が高くなるにつれ上昇する傾向を示し，リパーゼ活 性と総胆汁酸濃度との関係を濃度の対数值でプロットす ると図3に示すような相関が得られた。またリパーゼ活 性と総胆汁酸濃度の対数值との相関係数は $0.723(\mathrm{n}=$
30)であった.胆汁中胆汁酸の主成分であるCA と CDCA についてリパーゼ活性と濃度の対数值との関係を検討し た結果，CDCA については総胆汁酸の場合と同様の結 果が得られた $(r=0.732, n=30)$ (困 4 ) が, CA につ いては両者の間に相関は認められなかった（r=0.576, $\mathrm{n}=30$ )（困 5 ). さらに, G ZDCN a の標品を用いた実 験に打いてその濃度の対数值とリパーゼ活性との間の直 線性が確認できた（図 6).これらのことから胆汁中の 総胆汁酸濃度や CDCA 濃度とリパーゼ活性との間に密 接な関係があるものと思われる. 一方胆汁酸組成とリパ 一ゼ活性の関係を検討するため, 胆汁酸構成成分とリパ 一ゼ活性について重回帰分析を行ったところ, 表 1 に示 す結果を得た.リトコール酸（以下 LCA と略）とデオ キシュール酸 (以下 DCA と略) は今回の場合, 微量成 分であり偏相関係数も小さくリパーゼ活性への影暃はあ まりなく，またCA は胆汁中で最も多い成分でありなが ら偏相関係数は小さくこれもリパーゼ活性への影響は小 さいと考えられる. 結局 CDCA とUDCA の影響が比較 的大きかったと考えられる。

本来胆汁酸のリパーゼ活性に及ぼす影響は複雑で，反 応速度論的には低濃度では加速作用, 高濃度では阻害作 用を示し，これらは界面の物理化学的性質の変化 ${ }^{7,8)}$ 胆汁酸ミセルとリパーゼ閏の直接的な相互作用 ${ }^{9,102}$ とし 


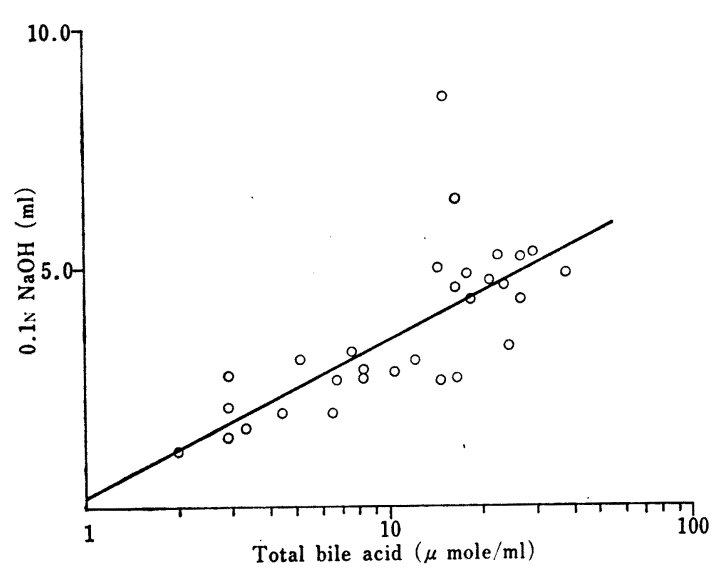

図 3. 総胆汁酸濃度とリパーゼ活性の関係

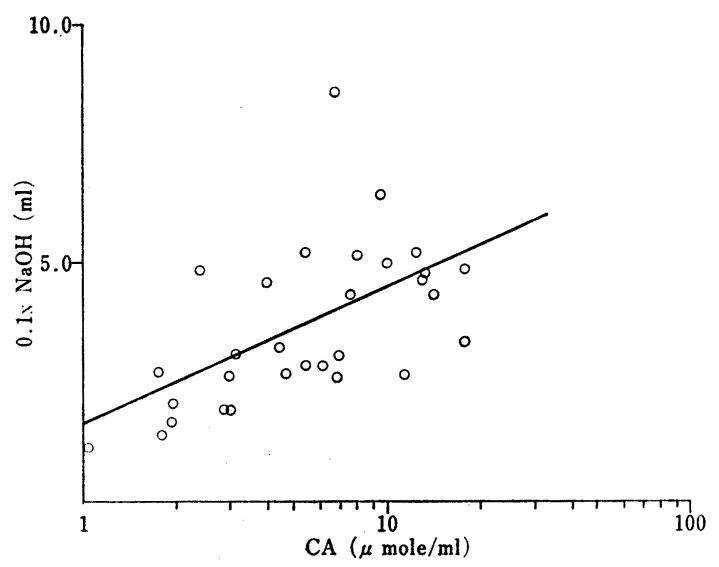

図 5. 胆汁中C A 濃度とリパーゼ活性の関係

て捉兄られている。一方, 胆汁酸は脂肪を乳化しその界 面積を增大させることによりリパーゼ活性を促進すると されており，事実りパーゼ活性は基質の絶対量ではなく エマルジョン粒子の界面積に依存することがわかってい る. ${ }^{11)}$ ま，リパーゼの脂肪分解反応の進行に伴い生成 した脂肪酸が界面に集積し，反応は急速に阻 害される が，胆汁酸ミセルはこれを可溶化し界面から除去してい

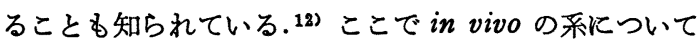
考えてみると，掑取された脂肪は十二指腸に抋いて胆汁 中の胆汁酸および膵液のリパーセににより十分な消化を受

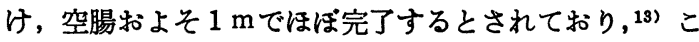
の間脂肪は生理的界面活性剂である胆汁酸の存在下腸管 の機械的運動等により乳化が促進され，先に述べた複雑 な影響の結果として反応が促進されるものと考えられ る.そこで，今回胆汁酸のリパーゼ活性に及ぼす影響を

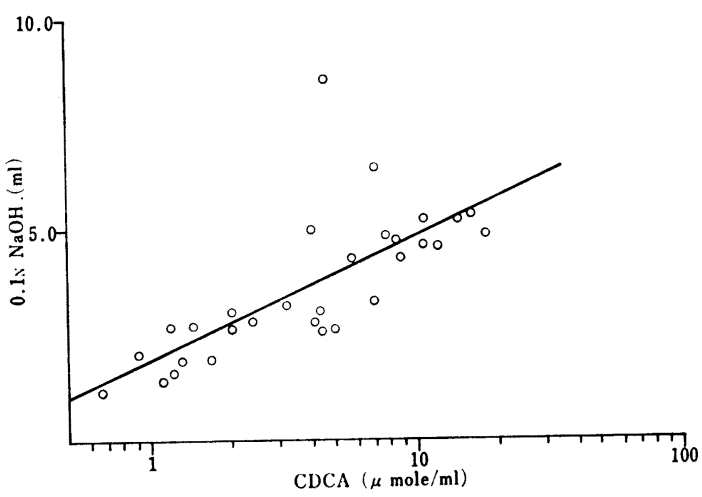

図 4. 䏣汁中 CDCA 濃度とリパーゼ活性の関係

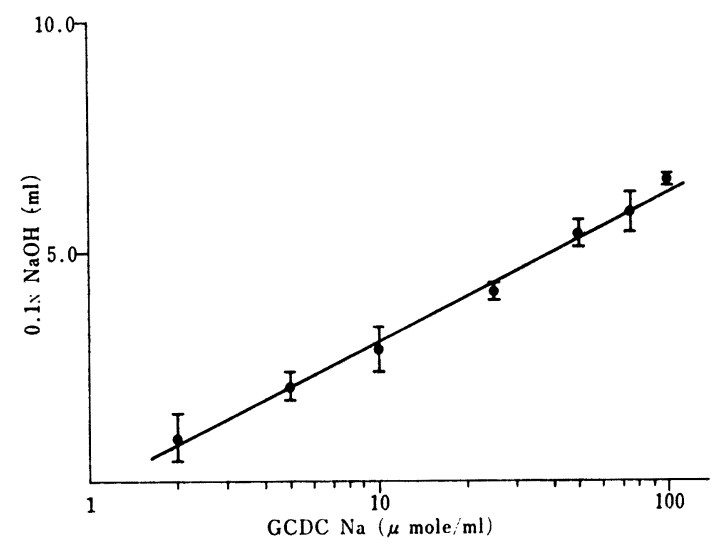

図 6. GCDCNa 濃度とリパーゼ活性の関係

表 1. 䏣汁酸構成成分とリパーセ活性の相関

\begin{tabular}{l|c|c|c|c|c}
\hline 䏣 汁 酸 & LCA & DCA & CDCA & CA & UDCA \\
\hline 偏相関係数 & 0.127 & 0.046 & 0.409 & 0.119 & 0.355 \\
\hline
\end{tabular}

検討するにあたり，反応速度論的考察を目的とせず，ま た従来行われているリパーゼ活性測定法のようにェマル ショョンとした基質ではなく，植物油をそのまま基質とし て用い，機械的振動を加える方法が最も胆汁酸の影響を 検討するらえで妥当であると考えた。な扳応が不均一 であることを考虑し 4 回の測定の平均值を用いることに した.

今回の実験結果から総胆汁酸瀑度を增加させることは 脂肪の消化を促進するうえで重要であり, 特にCDCA, UDCAの增加がよい結果をもたらすであろうと推測され 
る.現在 UDCA 製昘はコレステロール胆石の溶解,脂肪 の消化促進など愊広い目的で使用されているが，CDCA 製剤はコレステロール胆石の溶解が中心であり, リパー せ活性促進作用を介した脂肪の消化促進への応用も検討 の余地があると思われる。

なお，リパーゼ活性に影響を及ぼす因子として他にも リン脂質, 各種電解質などが考えられるが，今回は検討 を加えなかった．また今後 $\mathrm{pH}$ や反応時間などの条件が 今回得られた結果にどのように影響するかについても検 討を重ねる必要があると思われる。

俩辞 本研究にあたり䏣汁中䏣汁酸分析を行っていた だいたェーザイ株式会社に深謝いたします。

文献

1) Rachford: J. Physiol., 17, 72 (1891).

2) O.Fürth u. J.Schütz: Hofm. Beiträge, 9, 28 (1906).

3）大川博, 佐伯正紀, 岩崎守男: 基礎之臨床, 10, 57 (1976).
4）高田充隆, 佐藤信, 橋爪昭人, 平野善信, 尾崎照 美: 病院薬学, 7 (5), 265 (1981).

5）篠光正, 根津征夫, 立山正, 坂口健哉, 片山幸一, 堤淳三, 河部靖: 薬学雑誌, 99(4), 421 (1979).

6) S. Okuyama, N. Kokubun, S. Higashidate, D. Uemura, and Y.Hirata: Chem. Lett., 1979, 1443.

7) B. Borgström and C. Erlanson: Eur. J. Biochem., 37, 60 (1973).

8) C. Chapus, H.Sari, M. Sémériva, and P. Desnuelle: FEBS Lett., 58, 155 (1975).

9) D. Lairon, G. Nalbone, H. Lafont, J. Leonardi, N. Domingo, J. C. Hauton, and R. Verger: Biochemistry, 17, 205 (1978).

10) M.E. Momsen and H. L. Brockman: J. Boil. Chem., 251, 384 (1976).

11) G.Benzonana and P.Desnuelle: Biochim. Biophys. Acta, 105, 121 (1965).

12) H. Brockerhoff and R. G. Jensen: "Lipolytic Enzymes," Academic Press, New York, 1974.

13) B. Brogström, A.Dahlquist, G. Lundh, and J. Sjövall: J. Chim. Invest., 36, 1521 (1957).

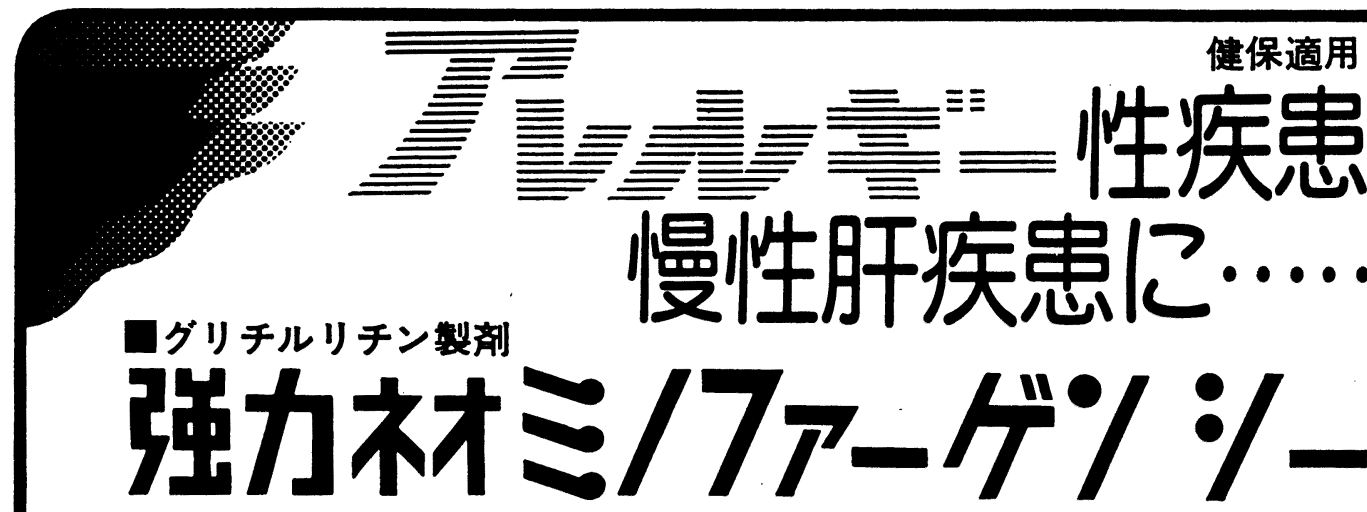

作用

抗アレルギー作用, 抗炎症作用, 解 瑇作用, インターフェロン誘起作用, および肝細胞障害抑制・修復促進作用 を有します。

○用法・用量 1 日1回，1管（ $2 \mathrm{ml}, 5 \mathrm{ml}$ ，または $20 \mathrm{~m} l)$ を皮下または静脈内に注射。 症状により適宜增娍。

堵性肝疾患には, 1 日 1 回, $40 \mathrm{~m} l$ を静脈内に注射。年龄, 症状により適宜增減。

包装 $20 \mathrm{ml} 5$ 管・ 30 管, $5 \mathrm{ml} 5$ 管・50管, $2 \mathrm{ml} 10$ 管・100管 米使用上の注意は, 製品の添付文書をご参照下さい。

○内服康法には

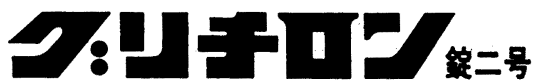

包装 1000 錠, 5000 錠

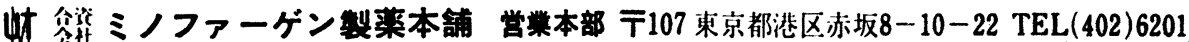

